\title{
Antígona y sus hermanos, del fratricidio a la fraternidad solidaria
}

\author{
Rizo Morales, María Elena Patricia \\ Antígona y sus hermanos, del fratricidio a la fraternidad solidaria \\ Synthesis, vol. 26, núm. 2, 2019 \\ Universidad Nacional de La Plata, Argentina \\ Disponible en: http://www.redalyc.org/articulo.oa?id=84662943003 \\ DOI: https://doi.org/10.24215/1851779Xe060
}

Esta obra está bajo una Licencia Creative Commons Atribución-NoComercial-Compartirlgual 4.0 Internacional. 
Artículos

\section{Antígona y sus hermanos, del fratricidio a la fraternidad solidaria}

Antigone and her Siblings, from Fratricide to Fraternal Solidarity

Maria Elena Patricia Rizo Morales

DOI: https://doi.org/10.24215/1851779Xe060

Universidad Panamericana, campus México, México

Redalyc: http://www.redalyc.org/articulo.oa?id=84662943003

mrizo@up.edu.mx

(D) http://orcid.org/0000000242784013

Recepción: 09 Septiembre 2019

Aprobación: 28 Noviembre 2019

\section{Resumen:}

Este trabajo es producto de una investigación realizada mediante el análisis de textos literarios, que tuvo como objetivo distinguir los elementos que inciden en la fuerza de los vínculos fraternos, tanto en su potencial destructivo como en su capacidad de convertirse en la mayor fuente de seguridad para la autorrealización de los hermanos. En este caso, el análisis de la conformación de la fratría de Antígona en la literatura griega demostró la influencia que tienen las circunstancias pretéritas en las relaciones fraternas; pero también hace patentes las virtudes requeridas para librar la lucha en contra del destino de manera heroica.

Palabras clave: Antígona, Vínculos fraternos, Familia, Literatura griega.

\section{Abstract:}

This paper is product of an investigation carried out by the analysis of literary texts, which aimed to discover the factors that intervene in the strength of fraternal ties either in its destructive sense or in its capability to become the main source of security in the self-realization of brothers and sisters. In this case, the study of the conformation of Antigone's phratry in the Greek literature demonstrated the influence of past circumstances in fraternal bonds, but it also made evident the virtues necessary to overcome the designs of destiny in a heroic way.

KEYWORDS: Antigone, Fraternal ties, Family, Greek Literature.

\section{INTRODUCCIÓN}

Los vínculos entre hermanos son el germen de las relaciones fraternales de camaradería entre ciudadanos, entre pueblos y entre culturas; muestran el camino que va de la guerra a la conciliación y al establecimiento de alianzas de paz y cooperación. Pelear y hacer las paces representan una de las prácticas que se aprende con los hermanos. Así, después de las grandes luchas en las que se enfrentan los hermanos, existe la posibilidad de constatar el alto costo que tiene la rivalidad, y es en ese momento precisamente cuando aparece la oportunidad de la conciliación y el establecimiento de pactos de unión, solidaridad y lealtad sobre los que se fincan las alianzas necesarias para el desarrollo de cada uno de los miembros de la familia. De no lograr dar este paso, el alejamiento de los hermanos congela los afectos o mantiene vivo el rencor y el recelo hasta conducir al fratricidio.

A lo largo de la historia, las relaciones fraternas han reflejado la natural dificultad de superar el interés individual egoísta para acceder a la identificación empática con los hermanos y después, con los amigos, compañeros o semejantes. Tanto los mitos como las leyendas y los relatos históricos dan cuenta de la intensidad emocional que envuelve las relaciones fraternas. La historia bíblica de José es un excelente ejemplo de la evolución de la rivalidad y envidia primitivas y su conversión en alianzas fraternas afectivas. Este relato del Génesis (37-40) explica el origen de los celos entre hermanos a raíz de la preferencia del padre por uno de ellos, por lo que en coalición deciden deshacerse de él, vendiéndolo como esclavo. Así llega José a Egipto en donde su tesón y fidelidad lo hacen merecedor de un lugar de importancia en el reino. Desde su posición de 
poder, José logra salvar a su familia y ser benefactor de su pueblo. Finalmente, el perdón, el amor y la confianza se imponen sobre los resentimientos del pasado y sobrevienen la paz y la prosperidad.

Fuera de la tradición judeocristiana también son repetidas las figuras históricas y literarias que se internan en el conflicto entre hermanos. El presente caso de estudio se centra en la diferente calidad de vínculos existentes en la tragedia Antígona, inspirada en mitos y leyendas ancestrales. Estos relatos revelan en su contenido una serie de fantasías, temores, incertidumbres e ilusiones que forman parte del inconsciente colectivo desde tiempos arcaicos y aún hoy en día siguen teniendo resonancia. Lo que les da permanencia a ciertos mitos es que tocan de manera muy fina los afectos humanos, las creencias, las aspiraciones y los grandes cuestionamientos de la humanidad, que tienen que ver con el origen de la vida, con el bien y el mal y con la idea de eternidad básicamente.

La idea central de este análisis es que, al mismo tiempo que la enemistad entre hermanos es capaz de producir las más feroces luchas fratricidas, el cultivo de alianzas fraternas es la mayor fuente de seguridad y motivación para la autorrealización humana. La fratría que forman los cuatro hijos de Edipo proviene de los más siniestros orígenes y por ello es imprescindible la aproximación a su estudio desde dos perspectivas: la intergeneracional, que parte del eje vertical proveniente de los antepasados y trasmitido de padres a hijos, y la intrageneracional que, como eje horizontal, se apoya en las mutuas identificaciones entre hermanos o pares, quienes se acomodan en la fratría conforme a factores del pasado y a eventos contemporáneos. El vertical es el eje fundante de la familia en sí, pues su prolongación es gracias a la procreación, y se remonta a todo un linaje. En el caso de Antígona y sus hermanos resulta muy revelador el tema del legado transgeneracional pues, como se verá, el intrincado conflicto que se presenta en la fratría proviene de graves transgresiones ancestrales a las leyes naturales que no fueron debidamente expiadas por sus actores. Se trata de filicidios, pederastia, incesto y parricidio, como se verá más adelante.

\section{EJE VERTICAL: LEGADO TRANSGENERACIONAL}

A través de la sucesión de generaciones de un linaje hay muchas cosas tangibles que se heredan, como los bienes materiales, los rasgos físicos y tendencias de personalidad, entre otras. Además, existen cuestiones inconscientes que se trasmiten de manera imperceptible y que ejercen un intenso efecto en las familias que van formando los descendientes. Se trata de legados, de consignas, mandatos o culpas no pagadas, que generalmente se mantienen ocultas porque responden a acciones que infringieron las normas morales resguardadas en la familia o fueron causa de gran vergüenza en el pasado, por lo que se les pretende hacer desaparecer. Es frecuente observar cómo se repiten conductas dañinas del pasado, a pesar del intento de evitarlas y, por misteriosos motivos, algún miembro de una nueva generación actúa de tal manera que reedita la experiencia que trató de eludir, como le pasó a Edipo que, sin intención, comete actos que continúan la cadena de transgresiones en su dinastía.

¿A qué responde este tipo de repeticiones? Haydée Faimberg (1996) las explica como un proceso al que llama "telescopaje" de las generaciones, a través del cual se transfieren contenidos psíquicos y experiencias difíciles de procesar por ser demasiado dolorosas o vergonzosas. En cada familia siempre hubo y habrá pérdidas, rompimientos y desgracias que se cuentan de cierta manera y así trasmiten su contenido elaborado por la palabra, pero hay ciertos dolores o afrentas que, debido a su intensidad, se vuelve casi imposible expresar en palabras, estos son los dramas familiares que traspasan generaciones a través de un contenido imaginario, más que real, en el que se mezclan temores y aflicciones, tal como sucede en los mitos y mitologías que circundan la genealogía tebana narrada en la literatura arcaica, desde la épica hasta alcanzar su máxima elocuencia en la representación dramática ateniense de la época clásica.

Como se verá más adelante, los mitos y leyendas en los que se basa el drama de Antígona, cuentan fábulas y episodios terribles a lo largo de varias generaciones que se suceden en el tiempo. Estos hechos consisten en aberraciones y ultrajes que atentan contra las leyes divinas y por tanto existe la convicción de que, mientras no 
queden expiados los daños, serán causa de maldiciones por parte de los dioses. La dinastía tebana finalmente obtiene la clemencia divina, gracias a los actos reparadores de Edipo y el sacrificio de su hija Antígona. Este último, no solamente recupera el honor de la familia, sino que al mismo tiempo libera a Tebas de la contaminación o miasma, producto de las graves transgresiones del pasado. Al pagar con su vida por las afrentas perpetradas por sus antepasados, Antígona obtiene el perdón y la liberación del pueblo entero y se convierte en pharmakós [фapuakós] ("chivo expiatorio"), ' como lo había sido Edipo, su padre.

El comportamiento de los hermanos, a pesar de que se regula de acuerdo a las condiciones que rodean a la familia, a la cultura en que se vive, las creencias, costumbres, orden del nacimiento y otros factores semejantes, sólo se logra entender en profundidad dentro de su génesis histórica, en la que intervienen al menos tres generaciones, especialmente si se trata de momentos críticos, o situaciones de grandes pérdidas o sufrimientos que se mantuvieron en silencio. Los legados transgeneracionales son estudiados en la psicología familiar (Boszormenyi-Nagy \& Spark, 1983), y se refieren a determinadas tareas, mandatos o encomiendas que recibe una nueva generación y pueden consistir en la salvaguarda de secretos familiares o la designación de un emisario que pague o haga pagar por los errores que no fueron purgados cabalmente en su momento.

La trasmisión de la culpa a través de generaciones ya formó parte del pensamiento religioso de culturas antiguas y también es parte de la tradición judeocristiana, la cual sostiene que la iniquidad de los padres repercute en las siguientes generaciones: " $i$ Castiga la maldad de los padres en los hijos y en los hijos de los hijos, hasta la tercera y cuarta generación!” (Éxodo, 34-7).

Para el análisis de los antecedentes genealógicos de Antígona fueron consultadas diferentes versiones de los mitos, a pesar de los elementos disímiles entre uno y otro relato, pues de esta manera se puede tener una imagen más completa de la concepción griega respecto a los conflictos no resueltos a través de generaciones de la dinastía tebana. Los siguientes son los sucesos sobresalientes en cada generación.

\section{Primera época: Expulsión de los hijos. Dispersión de la fratría}

El mito del ciclo tebano inicia con la fundación de Tebas por Cadmo, hijo del rey Agenor de Tiro, en Fenicia. Después de que Zeus raptó a su hermana mayor, la bella Europa, Agenor envió a sus hijos a recuperarla, con la advertencia de que no podrían volver si no era con ella. Al no encontrarla, cada uno de los hermanos se estableció en diferentes territorios, donde fundaron sus reinos. Cadmo llegó a Beocia, en donde fundó Cadmea que después se llamó Tebas. Ahí se casó con Harmonía, que era hija de dos dioses: Afrodita y Ares (Apolodoro, 3,4,2) y engendraron varios hijos, aunque el trono no fue heredado por ninguno de ellos, sino por su nieto Penteo.

En esta primera generación hay que notar la fuerza del mandato paterno en dos sentidos: el primero es la encomienda de cuidar el honor de las hermanas; y el segundo es la apertura a la exogamia, la resolución de que cada uno de los hijos se convirtiera a su vez en cabeza de una nueva familia y se reprodujera la estirpe. La afrenta de Zeus no es perdonada por el padre Agenor porque ese rapto constituye un deshonor para la familia, y por eso prohíbe que sus hijos vuelvan si no desagravian la injuria. Por otro lado, el secuestro de Europa marca el inicio de la expansión dinástica de los griegos.

\section{Segunda época: depravación y filicidio}

Los hijos de Cadmo y Harmonía fueron: Ino, Sémele, Ágave, Autónoe y Polidoro. El reino lo heredó Penteo, hijo de Ágave, pero no fue aceptado de buen grado por su primo Dioniso, hijo de Sémele y Zeus. Dioniso, envidioso de Penteo e indignado por no ser reconocido en su carácter de divinidad (por ser hijo de Zeus), se entrega a la venganza en contra de su familia. Con este fin, atrae a las mujeres a los festines orgiásticos hasta hacerlas perder la razón, y usarlas para destrozar al rey Penteo. Así, mediante artes engañosas, Dioniso logra 
inducir el comportamiento licencioso de Ágave y sus hermanas, las bacanales, que además de embriagarse con jarras completas de vino, corren a satisfacer su lujuria con sus amantes, justificando su proceder como si se tratara de ritos religiosos. Penteo se opone enérgicamente a estos cultos dionisiacos y en ese momento es asesinado por Ágave, su propia madre. En su delirio báquico, Ágave confunde a su hijo con una fiera a la cual descuartiza, y devora sus restos junto a sus hermanas las bacanales. Eurípides (trad. 1979) narra la escena de manera muy similar a la de Apolodoro (trad. 1985):

Había un griterío total; a la vez él, que gemía de dolor con todo lo que le quedaba de vida, y ellas con sus gritos de triunfo. Arrancaba una un brazo, otra un pie con su calzado de caza mientras en el descuartizamiento quedaban al desnudo sus costillas. Y todas, con las manos teñidas de sangre, se pasaban una a otra como una pelota la carne de Penteo (Bacantes, vv. 1130-1135).

A pesar de que Ágave clama de pena por haber confundido a su hijo con un animal salvaje, Eurípides hace hincapié en la oportunidad que tuvo de haber reparado a tiempo, pues no se apiadó de él, a pesar de haberlo tenido lo suficientemente cerca como para reconocerlo y escuchar sus súplicas.

Penteo que se sentaba en lo alto, cae desde la altura, derribado por tierra entre incontables gemidos... Su madre fue la primera en iniciar, como sacerdotisa, el sacrificio, y se echa encima de él. Penteo se arrancó la diadema del cabello para que le conociera y no lo matara la infeliz Ágave. Al mismo tiempo decía, acariciando su mejilla: “¡Soy yo, madre mía, yo, tu hijo! ¡Penteo, al que diste a luz en la morada de Equión! ¡Ten piedad de mí, madre, y no vayas a matar, por culpa de mis errores, a tu propio hijo!" (Bacantes, vv. 1110-1120).

Muerto Penteo, le sucedió al trono su tío Polidoro, quien no reinó por mucho tiempo, pues muy pronto murió y su hijo Lábdaco heredó el trono. Frazer (1921) comenta que Apolodoro da a entender que tanto Polidoro como Lábdaco fueron asesinados también por las bacantes por oponerse a la celebración de los ritos orgiásticos del culto a Dioniso (Apolodoro, 3.5.5; Pausanias, 2.6.2)

\section{Tercera época. Las transgresiones de Layo: homosexualidad, pedofilia, filicidio.}

Layo era aún niño cuando su padre murió y mientras cumplía la edad suficiente para acceder al trono fue desterrado de Tebas y acogido en Pisa por el rey Pélope, en cuya corte vivió, teniendo a su cargo la custodia de Crisipo, hijo del rey. Sin embargo, Layo ofendió gravemente a Pélope y traicionó su confianza, se enamoró de su hijo, lo raptó, lo violó y a causa de ello, algunos textos cuentan que Crisipo se suicidó (Apolodoro, 3.5.5). Por esta razón Pélope maldijo a la estirpe de los Labdácidas a exterminarse a sí misma.

Aquí es clara la ofensa de Layo, quien cobarde, retornó a Tebas ocultando su crimen. Un escolio a Fenicias (1760) de Eurípides, del mitógrafo Pisandro, relata que fue la diosa Hera, tutelar del matrimonio, quien envió la Esfinge a los tebanos desde Etiopía, indignada porque la impudicia de Layo con Crisipo había quedado impune (Bernabé, 1999). Una vez más la conciencia moral de la polis se escucha en el oráculo. Esquilo (trad. 1987) en Los Siete contra Tebas deja claro el ineludible peso del destino marcado por yerros del pasado, y en voz del coro se expresa el sentir ciudadano:

Sí. Quiero decir que la transgresión antaño nacida, castigada rápidamente, permanece no obstante hasta la tercera generación, cuando Layo violentó la orden de Apolo, aunque este le dijo tres veces en el pítico oráculo del ombligo del mundo que salvara nuestra ciudad muriendo sin descendencia. (Siete contra Tebas. 743-749)

La afrenta sexual cometida por Layo en contra de Crisipo fue relatada por Apolodoro (3.5.5); Tucídides (trad. 2013, 1.9); Pausanias (I.20.7); Esquilo (Siete contra Tebas, vv. 743-749); Eurípides (Bacantes, Introducción); Sófocles (E.R., v. 114), y repercute en tres generaciones a través de las maldiciones provocadas por la gravedad de la conducta pederasta de Layo. El hecho de que la injuria de Layo fuera relatada por tantos autores de la Grecia antigua es muestra de la advertencia contra la pérdida del autodominio que deja al individuo a merced de la hýbris (üßpıs), de la desmesura que lleva a los excesos, condición denostada 


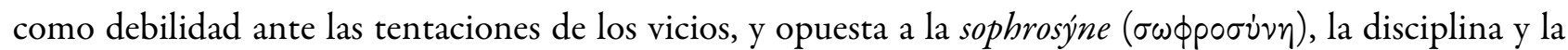
moderación.

$\mathrm{Al}$ regresar a Tebas y asumir el trono que le correspondía, Layo se casó con Yocasta, pero al no poder engendrar, acudió al oráculo, el cual le advirtió que no intentara tener hijos, pues de acuerdo a un designio divino, su hijo lo mataría y así daría fin a su estirpe.

El oráculo le anunció a Layo:

Layo, hijo de Lábdaco, suplicas una próspera descendencia de hijos. Te daré el hijo que deseas. Pero está decretado que dejes la vida a manos de tu hijo. Así lo consintió Zeus Crónida, accediendo a las funestas maldiciones de Pélope cuyo hijo querido raptaste. Él imprecó contra ti todas estas cosas (Edipo Rey, Prólogo).

El destino no se pudo burlar, Yocasta y Layo tuvieron un hijo, y a pesar del filicidio fallido de Layo, Edipo sobrevivió para cumplir la profecía. La tragedia de Edipo Rey presenta los sucesos que siguieron al nacimiento del hijo de los reyes de Tebas, cuando Layo, temeroso del mal augurio, decidió exponerlo, le perforó los tobillos, le ató los pies con una correa y lo envió a morir a la montaña. Sin embargo, fue encontrado por Peribea y Pólibo, reyes de Corinto, quienes lo adoptaron y lo nombraron Edipo, que significa "pies hinchados" (Martínez, en Eurípides, 1998). ${ }^{2}$

\section{Cuarta época: Parricidio e incesto}

Edipo creció con sus padres adoptivos y los amó, y por eso, cuando el oráculo de Delfos le vaticinó que mataría a su padre y desposaría a su madre huyó de ellos horrorizado para no cumplir con el terrible designio; sin embargo, el trágico juego del destino que Sófocles presenta, trata sobre las posibilidades del hombre para burlarlo, así que irónicamente, al escapar Edipo para evitar su suerte, se topó en el camino con su padre de sangre y, después de una reyerta, terminó matando a Layo sin saber quién era en verdad.

Como la infamia de Layo seguía siendo pasada por alto, la diosa Hera se encargó de darle su escarmiento a los tebanos y para eso envió a la Esfinge a mantenerlos aterrorizados, mientras imperaba la impunidad (Graves, 1985). Este monstruo devoraba a todo aquel que no supiera resolver sus enigmas, y así pasó mucho tiempo, hasta que Edipo la derrotó al resolver el enigma, de modo que la población quedó liberada. En reconocimiento a su proeza, Creonte le ofreció tanto el cetro, como la mano de la reina viuda. Entonces fue que Edipo desposó a Yocasta, ignorando ambos su verdadera identidad, y engendrando cuatro hijos. Edipo estuvo condenado aún antes de haber nacido, por el parricidio y el incesto que, al tratar de evitar, cometió. Así lo refleja Esquilo en el canto del coro de Los Siete contra Tebas:

Vencido por su propia irreflexión, llegó a engendrar su propia muerte, al parricida Edipo, que sembró el puro campo materno donde él se crio, con lo que osó hacer brotar una raíz llena de sangre. ¡Locura destructora de almas unió a los esposos! (...) Sí, ya está llegando a su cumplimiento la abrumadora liquidación de las maldiciones antaño imprecadas. (Siete contra Tebas, vv. 750-755).

Durante el reinado de Edipo la peste azotaba Tebas, cuando el oráculo de Delfos reveló que esta catástrofe no cesaría hasta que fuera castigado el asesino de Layo. Edipo, sin saber que él era el autor del crimen, maldijo al homicida, y en su búsqueda descubrió su doble ignominia. Al saberlo, Yocasta se suicidó y él se perforó los ojos con un prendedor de su vestido. Al castigarse de esa forma y lamentarse por ser víctima de culpas heredadas, maldijo a su descendencia.

En Fenicias (vv. 1608-1615) Edipo exclama:

Y después de haber matado a mi padre, malhadado de mí, vine al lecho de mi pobre madre y engendré hijos que eran mis hermanos, y los hice morir, heredando las maldiciones de Layo y pasándolas a mis hijos. Porque no soy yo tan loco que hubiera tramado eso contra mis ojos y contra la vida de mis hijos sin la decisión de alguno de los dioses. 
Al ver cercana su muerte, Edipo estaba cierto de haber cumplido su sentencia por las acciones nefastas que sin proponérselo había realizado. Sabía que su contrición y pena lo habían hecho merecedor del favor de los dioses, y así anunció la promesa de Febo al final de sus días, según la cual llegaría a un lugar donde descansaría en paz. Aquel que lo acogiera sería recompensado, pero quienes lo hubieran rechazado serían castigados. Las señales que se recibirían como garantía de la promesa del dios eran un sismo, un trueno o el rayo de Zeus en el momento de su muerte (Edipo en Colono, vv. 90-95).

La paz interior de Edipo proviene también del perdón y amor de sus hijas, que lo acompañan hasta su último día:

Tengo lo que más quiero. Ni aun si muriera sería ahora enteramente desgraciado, por el hecho de estar vosotras dos a mi lado. Apoyaos, hijas mías, una en cada costado abrazando a vuestro padre, y poned fin a la soledad anterior de este desgraciado vagabundo (Edipo en Colono, v. 1110).

No obstante, Edipo se mantiene implacable en cuanto a la condena de sus dos hijos varones. Cuando Polinices acude suplicante ante su padre en Colono, pidiendo su perdón y su gracia en la batalla que emprenderá contra su hermano para ganarle el trono de Tebas, Edipo no se apiada de él; por el contrario, renueva las maldiciones que había lanzado contra sus hijos por haberlo deshonrado. Condena a Polinices a morir a mano de quien comparte su linaje y a matar a aquel por quien fue desterrado. Deshonrar al padre es un acto imperdonable:

Por ello estas maldiciones tendrán más poder que tu actitud de suplicante y tus tronos, si la Justicia celebrada desde antiguo sigue sentada junto a las leyes de Zeus que rigen desde siempre (Edipo en Colono, v. 1385).

Sófocles da mucha importancia al significado de la muerte de Edipo, pues es un aviso a los ciudadanos sobre el perdón de los dioses cuando se cumple con las leyes divinas y se conduce la vida con piedad. El momento de la muerte se narra como algo sagrado, Edipo dispuso que nadie, excepto Teseo, rey de Colono, presenciara el momento de su muerte. Despide a sus hijas con palabras amorosas y se dispone a morir: "no podéis haber recibido de nadie un amor mayor que de este anciano sin el cual vais a pasar desde ahora el resto de vuestra vida" (Edipo en Colono, v. 1615).

Así, las promesas divinas se cumplen, y el mensajero relata el momento de su muerte:

De repente una voz de alguien le llama a gritos de tal modo que a todos se nos erizan súbitamente los cabellos por el terror. Un dios le llama repetidas veces de distintas maneras: “Eh, a ti, a ti, Edipo! ¿A qué esperamos para marchar? Ya hace rato que hay retraso por tu parte”. Y cuando él se da cuenta que la divinidad le llama, manda que se le acerque Teseo, rey del país, y una vez que lo hizo, le dijo: “¡Oh amigo querido! Da con tu mano a mis hijas la antigua garantía y vosotras, hijas, a él, y promete que nunca las abandonarás...” (Edipo en Colono, vv. 1625-1635).

La muerte de Edipo tiene un significado heroico de salvación que se extiende a la pólis, no sólo a la familia, libera a Tebas de las calamidades que sufrió por tanto tiempo, y además ofrece protección al lugar en el que descansen sus restos, que es Colono, a las afueras de Atenas. No se sabe de qué murió Edipo, pero el mensajero dice sorprendido que más bien parecería que algún enviado de los dioses se lo llevó o la tierra le abrió paso al lugar de los muertos, sin dolor ni sufrimiento, "cual ningún otro de los mortales" (Edipo en Colono, v. 1680).

\section{Quinta época: Fratricidio, fin de la dinastía, restauración del honor.}

El drama de la última generación de los Labdácidas se centra en el cumplimiento de las maldiciones provenientes no solamente de parte de Edipo, sino de las que había proferido antes Pélope, padre de Crisipo, contra la descendencia de Layo. Sólo la purificación ritual, kátharsis, podría liberar a la población tebana del míasma (Dodds, 1951). Así lo declara Tiresias a Creonte en Fenicias (vv. 865-870): 
Hace ya tiempo que esta tierra está contaminada (...) desde que engendró hijos Layo a despecho de los dioses y dio el ser al desdichado Edipo, esposo de su madre. Las sanguinolentas desgarraduras de sus ojos son un testimonio de la sabiduría de los dioses y un ejemplo para Grecia.

Desde la epopeya, los errores fatales de los héroes se calificaban como hamartía [ $\dot{\alpha} \mu \alpha \rho \tau i \alpha]$, lo que significaba que sus acciones no respondían a causas humanas, sino que provenían de la instigación de los dioses, de áte, que hacía presa de los hombres y se apoderaba de su alma provocando un frenesí o locura que los conducía a cometer faltas. El sufrimiento y muerte de Edipo no había terminado de redimir los terribles yerros, la hamartía, pues aun sin haber actuado conscientemente de lo que hacía, sus actos pesaron en demasía sobre su descendencia, como lo declara el coro en Fenicias (v. 815).

Ciertamente, lo que no nació bueno nunca será bueno, ni tampoco los hijos concebidos en contra de la ley, manchados por la sangre parricida, de una madre que frecuentó el lecho de su propio hijo.

Esta es una generación que conoce perfectamente la carga ancestral que arrastra. No recibe este peso con reproches ni se culpa a quienes cometieron los actos reprobables que han causado tantos males en la dinastía. Saben simplemente que su destino ha sido dictado por la irreverencia en la que han incurrido una y otra vez sus antepasados, provocando la ira de los dioses. Edipo se considera víctima de las impiedades tanto como sus hijos. En Antigona el coro lo lamenta así:

Veo que desde antiguo las desgracias de la casa de los Labdácidas se precipitan sobre las desgracias de los que han muerto, y ninguna generación libera a la raza, sino que alguna deidad las aniquila y no les deja tregua (Antígona, vv. 594-596).

La maldición de Edipo a sus hijos se cumplió al morir los dos hermanos uno a manos del otro por pelear la herencia paterna del reino de Tebas. Existen versiones contradictorias sobre a cuál de los dos le correspondía la primogenitura. En Edipo en Colono, Polinices asegura ser el mayor, pero en Fenicias (v. 60), Yocasta sostiene que Etéocles era mayor. El caso es que, para evitar que la profecía se cumpliera, Yocasta convenció a sus hijos de turnarse el poder anualmente; pero una vez que Etéocles subió al trono, no lo quiso ceder a Polinices. Cuando este se armó con un ejército de argivos para reclamar el cetro paterno, Yocasta envió a Antígona para interponerse entre los dos, aunque fue inútil, la maldición se cumplió (Fenicias, v. 85).

El rey, su tío Creonte ordenó unos funerales solemnes para Etéocles, pero prohibió el entierro de Polinices, y a partir de este hecho se desarrolla la tragedia de Antígona por defender el derecho a la sepultura de su hermano, por lo que da su vida y al mismo tiempo cierra el ciclo tebano y extermina las maldiciones sobre Tebas, pues ya había advertido el adivino, Tiresias, no podía permitirse que ninguno de los hijos de Edipo fuera ciudadano ni reinara Tebas "porque un demon los posee y van a destruir la ciudad” (Fenicias, v. 885).

En cuanto a las relaciones fraternas, quiero resaltar aquí los elementos familiares heredados, que pueden terminar en el desastre anunciado por eventos pretéritos o pueden conducir a la ruptura con una cadena de catástrofes, a costa de acciones radicales de las nuevas generaciones. Transgresiones tan serias como pederastia, filicidio, parricidio, incesto, tenían y tienen aún hoy en día, consecuencias severas en el desarrollo individual, en la convivencia social y en la salud mental y espiritual de los miembros de la familia en una misma generación o en generaciones sucesivas. La gravedad de este tipo de actos no puede purgarse con un arrepentimiento simplemente, sino que exige acciones radicales de reparación para obtener el perdón. Por eso tantas muertes se suceden una tras otra al conocer la verdad de Edipo, misma que fue acallada vilmente por Layo, con intentos cobardes de engañar a los dioses y a los hombres, indiferente ante el sufrimiento que ocasionaba a su familia, hasta llegar al filicidio (aunque no triunfara en su intento).

El peso de la culpa genealógica sólo puede ser liberado mediante el sacrificio autoimpuesto, primero el de Edipo, al cegarse y optar por el destierro, lo que le otorga la indulgencia de los dioses y el respeto de los hombres. Al final, el sacrificio de Antígona logra restaurar el honor de la dinastía y el desagravio completo, por su valentía obtiene el reconocimiento de los tebanos. En Antígona el coro advierte: "Llegando a las 
últimas consecuencias de tu arrojo, has chocado con fuerza contra el elevado altar de la Justicia, oh hija. Estás vengando alguna prueba paterna" (v. 855).

\section{EJE HORIZONTAL: LA FRATRÍA}

\section{Evolución del vínculo fraterno}

La armonía en las relaciones interpersonales no se da por generación espontánea, sino que requiere procesos de madurez, voluntad y esfuerzo para vencer la inmediatez de la inclinación a la satisfacción individual, sin tener en cuenta las necesidades de los demás, como sucede con cualquier infante humano. El proceso de acomodo y adaptación en el desarrollo humano no es fácil, pero ayuda el hecho de tener hermanos, con quienes se tiene la primera experiencia de interacción entre iguales. Serán útiles los conceptos teóricos de Czernikowski, Berlfein y otros (2003), para analizar la evolución de la relación entre hermanos, que puede verse como el paso a través de diferentes etapas evolutivas del vínculo, desde la rivalidad hasta la unión afectiva. Desde esta concepción, se explican las diferentes modalidades del vínculo a través de diferentes "tiempos" de un proceso de madurez en los que se aprenden a manejar de manera racional las tensiones y conflictos hasta formar una alianza de lealtad y solidaridad fraterna. Siguiendo el análisis de las condiciones que dan lugar a la fratría de Antígona, proseguiré ahora con el enfoque del núcleo de hermanos y las particularidades de cada uno de los vínculos que sostienen entre sí.

\section{Primer tiempo: rivalidad.}

Este primer tiempo se caracteriza por la dificultad de los hermanos de condescender ante los reclamos de los otros. Es una etapa de competencia y enfrentamientos para ganar la atención, el cariño y el reconocimiento de los padres. También se lucha por ocupar el lugar principal en la fratría, desde donde ejercer dominio sobre los demás.

El hijo mayor suele ser designado por los padres como epígono de la generación precedente, y él mismo puede asumir este legado en identificación con el padre, cubriendo algunas funciones no desempeñadas por aquel, sea por ausencia o por incapacidad, mientras que el hermano menor tiene la posibilidad de aventurarse a descubrir y conquistar nuevos territorios.

En los hijos de Edipo, aunque no hay precisión sobre cuál es el mayor, el rol de primogénito lo desempeña Etéocles, que asume el trono heredado del padre sin intención de cederlo cuando le toca en turno a su hermano. Polinices mientras tanto se va a conquistar nuevos territorios y a su regreso, ante la negativa de Etéocles de cumplir con su palabra, le declara la guerra junto con los siete argivos, lo que será tema de Los siete contra Tebas, de Esquilo (trad. 1987).

El ataque entre los dos hermanos es un ejemplo claro de lo que se juega en la lucha fratricida. La indignación de Polinices surge del hecho de ser burlado por Etéocles, y por incumplir la promesa que ambos hicieron a su madre.

Sófocles, en Edipo en Colono (vv. 1422-1425) presenta la rivalidad entre los dos hermanos, notoria en las palabras de Polinices: .Es vergonzoso huir y también que yo, el mayor, sea así objeto de burla por parte de mi hermano." 3

El lugar de poder es menos importante para él; no así para su hermano, aferrado al trono, como el bien más preciado, por encima del honor y de la lealtad familiar. Etéocles sostiene la tiranía como el mayor de los bienes por la cual vale todo tipo de injusticias y crímenes. Así defiende su posición ante su madre que le suplica ceder para evitar que se cumplan los designios paternos: 
... bajaría al fondo de la tierra, si fuera capaz de realizar tales acciones, con tal de retener a la mayor de las divinidades: la

Tiranía. Así, pues, ese bien, madre, no estoy dispuesto a cederlo a otro en lugar de conservarlo para mí (Fenicias, vv. 505-520).

Sófocles no retrata claramente la personalidad de los dos hermanos, pero Eurípides, en Fenicias, se detiene a describir con detalle, en voz del Mensajero, los eventos que reflejan características de sus personajes:

... Polinices todavía respiraba y, al ver a su hermana y a su vieja madre, dijo: "Me muero, madre, siento pena de ti y de mi hermana, y de mi hermano muerto. Que llegó a ser mi enemigo; pero, con todo, era mi hermano" (1440-1445).

\section{Segundo tiempo: conjunción}

Este tiempo representa un paso adelante, es el de conjunción (Berlfein et al., 2003), de enlace y coincidencia, porque a través del raciocinio se reconocen las ventajas de la reconciliación, se debilita el antagonismo e inicia la mutua identificación con base en las coincidencias de origen y crianza. En esta etapa los hermanos aprenden el beneficio compartido del apoyo y protección que pueden darse unos a otros ante amenazas externas. Pero este es apenas el inicio del proceso de socialización, si la fratría no se abre al mundo externo, en la comunidad, la conjunción puede convertirse en una especie de amalgama, unida más por la timidez y el temor al "peligro" externo, que por un sentimiento de gozo por estar juntos. La permanencia en este estado obstaculiza la individuación y la diferenciación de cada uno como persona única y autónoma. En su forma extrema conduce a coaliciones de complicidad endogámica defensiva ante cualquier influencia externa, ya sea de los mismos padres o de cualquier grupo externo que se viva como amenazante. Entre Etéocles y Polinices pareciera que hay indicios de conciliación para evitar la destrucción, pero se trata de algo muy efímero, porque ninguno de los dos está dispuesto a ceder en lo fundamental. Así se percibe esta breve disposición a unirse en Fenicias:

Polinices: Incluso ahora estoy dispuesto, si recibo lo que es mío, a reenviar el ejército fuera de esta tierra, y a vivir en la casa familiar cumpliendo mi turno, y a cedérselo de nuevo a él por el mismo plazo. (Fenicias, vv. 480-490).

Etéocles: Hubiera debido, madre, tratar él de conseguir la reconciliación sin acompañamiento de armas, ya que la palabra razonable lo conquista todo, al igual que puede someterlo el hierro de los enemigos. (Fenicias, vv. 515-518).

En esta etapa, la función de Ismene es destacada, su fin es mantener a sus hermanos a salvo, mantener la unión y protegerse del peligro que asecha a su hermana en su desafío a la ley. En oposición a Antígona, argumenta a favor de la obediencia civil, y del cumplimiento con su rol de mujeres. Ismene es realista, se muestra conforme con la situación que les tocó vivir, amorosa con su familia, pero temerosa de arriesgarse a una empresa que las pone en peligro de muerte: "tenemos que obedecer en esto y en cosas aún más dolorosas que estas (...) el obrar por encima de nuestras posibilidades no tiene ningún sentido” (Antígona, v. 65).

El personaje de Antígona en ningún momento es de resguardo porque ella siente que su misión no es mantener la tranquilidad, sino restaurar el honor de la familia y cumplir con sus deberes de hija y hermana, antes de plantearse una visión de su propio porvenir.

\section{Tercer tiempo: disyunción}

Este es el tiempo de desligar, de disyunción (disjungere), en el sentido de destrabar la conjunción y dar inicio a la sana separación de los hermanos para abrir las puertas a otras conjunciones exógenas necesarias para su desarrollo, primero con amigos y compañeros y posteriormente en la alianza conyugal o cualquier otro tipo de vocación de vida, como la religiosa, militar, etc. Para que se dé este paso de separación de manera armónica y sin ruptura de vínculos, debe existir en la familia de origen un elevado grado de confianza y amor ya que, si predomina la agresión y la inseguridad, la separación se dará como huida de un ambiente familiar inhóspito, que expulsa a sus miembros. Lo importante en este tiempo es que se mantenga la alianza fraterna que permita mantener el vínculo a pesar de la diferenciación de objetivos o proyectos de vida personales. 
Este es un tiempo de gran riqueza y hace falta fuerza de carácter para lograrlo, pues las separaciones siempre provocan sentimientos dolorosos que se superan por el entusiasmo que causan los nuevos proyectos. Cuando las personas son débiles prefieren evitar el sufrimiento de dejar atrás un estilo de vida conocido y se mantienen en el estadio de conjunción.

En la disputa fraterna, la disyunción puede ocurrir por el odio que expulsa a uno o varios de los hermanos, otra forma de fratricidio porque lo que se pretende es el exterminio y la desaparición perene del hermano que se percibe como enemigo. Precisamente esta es la expulsión de Polinices por Etéocles (Fenicias, vv. 625-630): “Sal del territorio! Verazmente te puso padre el nombre de Polinices por inspiración divina, que es una invocación de discordias". ${ }^{4}$

Y lamenta así Polinices su suerte:

A la tierra que me crio y a los dioses pongo por testigos de que, despojado de mis honras, sufriendo pesares, me expulsan de mi tierra, como si hubiera nacido esclavo, y no hijo del mismo padre, de Edipo. Y si algo te ocurre a ti, ciudad, no me culpes a mí, sino a este. Porque no vine por gusto, y a mi pesar me echan de mi tierra.

El odio al hermano es devastador y el deseo de exterminio va más allá de la vida, pensando en su muerte en la pelea, Etéocles le pide a Creonte que prohíba el entierro del cadáver de Polinices:

A la ciudad y a ti esto os encomiendo, Creonte, si se impone nuestra causa, que el cadáver de Polinices jamás sea sepultado en este suelo tebano, y que quien trate de enterrarlo perezca, aunque sea alguno de nuestros allegados (Fenicias, vv. 775-778).

Creonte le cumple el deseo. Por lo contrario, Antígona, no puede desligarse de su legado, no osa pensar en su propia felicidad, en sus bodas ni en su futuro sin haber cumplido con su cometido familiar. Sin embargo, sabe separarse cuando es preciso, a pesar de lo doloroso que pueda resultar, y así lo hace con su querida hermana Ismene, a fin de permitirle hacer su vida sin tener que sacrificarla por mantenerse unidas. En Antígona (vv. 550-555) intenta facilitarle la separación para fincar su porvenir:

\section{Ismene: ¡Ah, cómo temo por ti, desdichada! \\ Antígona: No padezcas por mí y endereza tu propio destino. \\ Ismene: ¡Ay de mí, desgraciada! ¿Y no alcanzaré tu destino? \\ Antígona: Tú has elegido vivir y yo morir}

Este es un tiempo que requiere de valor y confianza, pues se deja atrás un estado anterior de convivencia cotidiana y se avizora un futuro aún incierto al tomar decisiones individuales que quebrantan la estabilidad de la familia. Cada salida de un miembro supone un desequilibrio en la composición familiar que requerirá cierto tiempo restituir. Es por eso que las grandes decisiones requieren del trabajo reflexivo interior pata actuar de manera asertiva y oportuna para solucionar problemas y prevenir desastres. Con estas bases, Antígona se comunica con entereza, clara y directamente con sus hermanos. A Polinices -a diferencia de la petición de su madre- le pide que regrese con su ejército a Argos y no cause la destrucción que se ha profetizado (Edipo en Colono, vv. 1413-1415). Trata de lograr una separación que podría evitar la aniquilación. El mayor logro de este paso de disyunción es mantener el vínculo a pesar de la distancia.

\section{Cuarto tiempo: solidaridad}

El acceder a esta etapa de evolución en los vínculos fraternos es signo de que se ha adquirido la capacidad de convivir en armonía con los demás, es la característica de sociabilidad que inclina al hombre a sentirse unido a sus semejantes y a cooperar con ellos (Czernikowski, 2003). Este es un tiempo en el que el vínculo fraterno de confianza se ha fortalecido tanto como para dar la seguridad de que la unión fraterna se mantendrá a pesar de las diferencias de pensar o de sentir, sin importar tampoco la lejanía geográfica. Un hermano solidario va más allá de la conjunción que se da en el segundo tiempo, la diferencia es que en este cuarto tiempo hay 
dinamismo en las relaciones, la motivación de apoyarse y mantenerse unidos no proviene del temor sino de la confianza de que se vencerán los obstáculos y se podrá hacer frente a la adversidad. La solidaridad indica que se ha alcanzado una diferenciación clara entre uno y otro. Como lo expresa Czernikowski (2003, p. 276):

No se trata del amor al prójimo porque somos todos iguales. No somos todos iguales. Más aun, somos todos diferentes. Pero es en esa diferencia, en la aceptación de la singularidad donde se constituye la solidaridad.

Por ello, el amor no puede fundarse en la idea de igualdad que podría indicar una prolongación narcisista, sino que precisamente la diferencia es prueba de solidaridad, y esta es una virtud que se practica más allá de la familia, con los miembros de la comunidad humana, en una fraternidad extendida.

Entre las dos hermanas, Antígona e Ismene, hay un lazo de solidaridad que prevalece en el fondo, a pesar de sus diferencias. Las posturas de ambas frente al edicto de prohibición del entierro de Polinices es completamente opuesta. Ismene considera que la sentencia debe obedecerse y argumenta a favor de su convicción; Antígona defiende la lealtad familiar por encima de edictos que se oponen a leyes naturales. Sin embargo, a la hora del juicio que las condenará a muerte sin duda alguna, Ismene se muestra dispuesta a asumir la culpa de una acción en la que no participó, y se presenta junto a su hermana ante Creonte para recibir el castigo. Este es un sacrificio que Antígona no permite y por protegerla del castigo, sus palabras son muy tajantes (Antigona, vv. 530- 550):

Corifeo: He aquí a Ismene, ante la puerta, derramando fraternas lágrimas. Una nube sobre sus cejas afea su enrojecido rostro, empapando sus hermosas mejillas.

Ismene: He cometido la acción, si esta consiente; tomo parte en la acusación y la afronto.

Antígona: Pero no te lo permitirá la justicia, ya que ni tú quisiste ni yo me asocié contigo.

Ismene: En estas desgracias tuyas, no me avergüenzo de hacer yo misma contigo la travesía de esta prueba.

Ismene: ¡Hermana, no me prives del derecho a morir contigo y de honrar debidamente al muerto!

Antígona: No quieras morir conmigo, ni hagas cosa tuya aquello en lo que no has participado. Será suficiente con que yo muera.

\section{Conclusiones}

La solidaridad se aprende con los hermanos, pero es una virtud que no se limita al ámbito familiar, sino que se extiende al entorno social, reconoce al mundo como un espacio abierto a la fraternidad entre todos los seres humanos, en cuanto semejantes, pero también en las diferencias.

En la familia, la lealtad, la solidaridad y el amor que une a los hermanos son fruto de un proceso de crecimiento físico y espiritual que logra vencer las tendencias narcisistas, centradas en el individualismo, para dar lugar a los afectos que acompañan conductas de cuidado y protección, mismos que requieren a su vez de cualidades humanas como la empatía, el altruismo, la cercanía afectiva y la resiliencia, entre otras.

Los vínculos fraternos son capaces de generar los más elevados actos en beneficio de los hermanos y de la humanidad, siempre y cuando se cumpla con las leyes no escritas de la fraternidad y se mantenga un lazo afectivo tanto en la línea horizontal, entre hermanos, como en la vertical, con los padres y con su ascendencia.

Una característica principal del vínculo que Antígona sostiene con sus hermanos es la lealtad, que es muy patente en la cercanía que mantiene con su padre durante toda su vida y en su entrega por cumplir con sus deberes de hermana y con su familia en toda su extensión. Debido a la lealtad, Antígona es capaz de subordinar el interés individual a favor de una acción que contribuye al bien general. Se conduce con dignidad y valentía. Asume su legado en la familia y está dispuesta a defender lo que considera como obligaciones sagradas inquebrantables por encima de su propia vida. Su fortaleza interior la convierte en el mayor soporte emocional y espiritual de cada uno de los miembros de su familia. En su entrega se manifiesta la virtud y el cariño.

¿Será posible hacer inferencias válidas sobre los vínculos fraternos en nuestras sociedades contemporáneas a partir del estudio del caso de Antígona y sus hermanos? ¿Podremos identificarnos con los conflictos y las 
conductas que suscita la relación fraterna en épocas tan remotas? Las leyendas, los mitos y las historias de todas las culturas representan en imágenes pictóricas o verbales las experiencias más contradictorias de los hombres. Los fratricidios y la expulsión de un hermano son repetidos relatos legendarios. Más allá del sentido familiar del hermano, en las comunidades llamamos "lazos fraternales" a los que se establecen entre compañeros, amigos o culturas. Tanto los odios fratricidas como los amores fraternos se extienden socialmente en guerras civiles o por lo contrario, en actos de solidaridad ciudadana, en sacrificios altruistas por salvar la vida o el honor de los seres cercanos, por los compatriotas o aquellos hermanos que más lo necesiten, como el sacrificio de Antígona por recuperar el honor de su familia y salvar a toda Tebas de la calamidad que la azotaba por los crímenes que habían quedado impunes.

\section{REFERENCIAS}

García Gual, C. \& C. Serrano (Eds.) (1985) Apolodoro. Biblioteca. Madrid: Gredos.

Berlfein, E., Czernikowski, E., Gaspari, R., Gomel, S., Matus, S., Moscona, S., \& Sternbach, S. (2003). Entre hermanos Sentido y efectos del vinculo fraterno. Buenos Aires: Lugar Editorial.

Boszormenyi-Nagy, I., \& Spark, G. (1983). Lealtades invisibles. Buenos Aires: Amorrortu.

Czernikowski, E. (2003). Lo fraterno en la cultura. En Entre hermanos. Sentido y efectos del vinculo fraterno. Buenos Aires: Lugar Editorial.

Dodds, E. (1951). The Greeks and the Irrational. Berkeley: University of California Press.

Cabello Álvarez, B. (Ed.) (1986). Esquilo. Tragedias. Madrid: Gredos.

Martínez Díez, A. (Ed.) (1979). Eurípides. Tragedias III. Madrid: Gredos

Faimberg, H. (1996). A la escucha del telescopaje de las generaciones: pertinencia psicoanalítica del concepto. En M. Enríquez; J. J. Baranes; R. Kaës, H. Faimberg Trasmisión de la vida psíquica entre generaciones (pp. 130-145). Buenos Aires: Amorrortu.

Frazer, J. (1921). Apollodorus, The Library. Cambridge: Harvard University Press. Recuperado de http://www.perse us.tufts.edu/hopper/text?doc=urn:cts:greekLit:tlg0548.tlg001.perseus-eng1:3.5.5

Graves, R. (1985). Los mitos griegos II. Madrid: Alianza Editorial.

Pausanias. (1918). Pausanias, Description of Greece. Retrieved January 19, 2017. Recuperado de http://www.perseu s.tufts.edu/hopper/text?doc=Paus.2.6.1\&lang=original

Facultad de Teología. Universidad de Navarra (Ed.) (2001). Sagrada Biblia. Pamplona: Universidad de Navarra.

Bergua, J. (Ed.) (2000) Sófocles. Tragedias. (Vol. 1). Madrid: Gredos.

Rodríguez M., E. (Ed.) (1990). Tucídides. Historia de la Guerra del Peloponeso. Madrid: Gredos.

\section{NoTAS}

1 El chivo expiatorio fue una figura familiar para los griegos que consistía en el sacrificio de alguien para lograr el perdón por alguna transgresión severa que otras personas hubieran cometido. De esta manera se obtenía la redención.

2 La nota de Martínez Diez en las Fenicias, hace mención a la interpretación de Lévi-Strauss, señala que este nombre, en línea con los de sus antecesores, Layo (el “Torcido") y Lábdaco (el "Patizambo"), aludiría a la dependencia íntima de Edipo con la tierra, sobre la que torpemente camina.

3 En Edipo en Colono (v. 1422) Polinices dice ser el mayor, mientras que en Fenicias (vv. 70-75) Yocasta presenta otro orden de nacimiento: Etéocles, Polinices, Antígona e Ismene.

4 La etimología del nombre significa poly: ("mucho”), neîkos: (“discordia”).

\section{BY-NC-SA}

